\title{
Differences in Hemoglobin Levels Before Menstruation and Post Menstruation Students of Sport Education Department Faculty of Sport Science University of Padang
}

\author{
Eldawaty $^{1^{*}}$ and Desi Novita Sari ${ }^{2}$ \\ ${ }^{12}$ Sport Education Program, Faculty of Sport Science, Universitas Negeri Padang, Indonesia \\ *Corresponding author. Email: eldawaty1971@ @mail.com ${ }^{l}$
}

\begin{abstract}
Initial observations made by researchers in the field, many female students majoring in Sports Education experienced a decrease in blood hemoglobin levels after menstruation, this interfered with the learning process and the student's daily activities. This study aims to see the differences in hemoglobin levels before menstruation and post-menstruation in female students majoring in Sports Education, Faculty of Sport Science, University of Padang. This research was conducted by applying quantitative design with the comparative approach. The results of data analysis performed by $t$ test, so Ho is accepted if, $t$ count $>\mathrm{t}$ table with a significant level of 0.05 , namely; there is a difference in blood hemoglobin during menstruation and post-menstruation. Be accepted if $t_{\text {hitung }}>t_{\text {tabel }}$ to a significant degree 0,05 that it $t_{\text {hitung }} 2,745>t_{\text {tabel }}$ 2,093; There is a significant difference between Hb before menstruation and post-menstruation among students majoring in Sports Education.
\end{abstract}

Keywords: Hemoglobin, Menstruation, Anemia

\section{INTRODUCTION}

Hemoglobin is a protein from erythrocytes contained in red blood cells that contains iron and functions as a transport of oxygen from the lungs to all body tissue cells. (Gunadi et al, 2016). Decrease in the number of red blood cells or a person's hemoglobin $(\mathrm{Hb})$ concentration in the blood is below normal values due to abnormalities in cell formation, bleeding or iron absorption disorders. Anemia can affect men and women, both children, adolescents, adults and ages further but the more frequently at risk of anemia are women with menstrual states. Low hemoglobin levels caused by menstruation can have negative effects on adolescent girls such as fatigue, weakness, dizziness, decreased concentration of learning and cause a pale face which is a symptom of anemia. (Prastika, 2011).

Based on the results carried out by researchers related to the Preliminary Study using two respondents, it was found that the hemoglobin value in the blood before menstruation was normal and the hemoglobin value after menstruation was abnormal, which was lower. Lack of hemoglobin levels in the blood can cause nerve cells and metabolism in the body to work not optimally. If the hemoglobin level in the blood becomes low, it will trigger symptoms of mild anemia, anemia is a condition in which a person's hemoglobin level is less than normal values. This is due to a decrease in the quality and quantity of red blood cells. Mild anemia can also affect the ability to concentrate in studying, reduce physical abilities, reduce body freshness, pale face, dizziness, decreased immunity so that it is prone to disease and feeling tired, tired and lethargic which also causes decreased productivity. (Wahyuningsih and Astuti, 2012) Abnormal hemoglobin levels in the blood due to menstruation can be overcome by adequate rest, consuming foods containing iron, increasing vitamin $\mathrm{C}$ intake, adequate exercise and getting used to a healthy lifestyle. Based on the description above, the researchers wanted to know the differences in hemoglobin levels before menstruation and after menstruation.

\section{METHODOLOGY}

This research was conducted by applying quantitative design with the comparative approach. The research design in this study, using the test method for direct data collection. The stages in this study were the researcher collecting data on the hemoglobin level of the sample. This research was conducted at the Faculty of Sport Sciences, University of Padang. The population in this study were all students of the Faculty of Sport Sciences, State University of Padang. The sample in this study was planned to be female students majoring in 
Sports Education, Faculty of Sport Science, University of Padang starting in the fourth semester.

Data collection techniques in this study were analyzed using statistical normality tests and t-test.

\section{RESULTS AND DISCUSSION}

a. Research result

Table 1. Research Results Differences in Hemoglobin Value before Menstruation and Post Menstruation in Sports Education Students

\begin{tabular}{|c|c|c|c|c|}
\hline Nama & Pretest & Postest & $\mathrm{D}=\mathrm{X}^{1}-\mathrm{X}^{2}$ & $\mathbf{D}^{2}$ \\
\hline $\mathrm{S} 1$ & 14.5 & 11.3 & 3,2 & 10,24 \\
\hline S2 & 13.5 & 10.9 & 2,6 & 6,76 \\
\hline S3 & 14.2 & 9.5 & 4,7 & 22,09 \\
\hline S4 & 13.8 & 12.0 & 1,8 & 3,24 \\
\hline S5 & 16.2 & 12.5 & 3,7 & 13,69 \\
\hline S6 & 13.8 & 10.3 & 3,5 & 12,25 \\
\hline S7 & 13.5 & 10.5 & 3 & 9 \\
\hline S8 & 14.0 & 9.7 & 4,3 & 18,49 \\
\hline S9 & 15.7 & 11.0 & 4,7 & 22,09 \\
\hline S10 & 15.3 & 11.5 & 3,8 & 14,44 \\
\hline S11 & 13.8 & 12.7 & 1,1 & 1,21 \\
\hline S12 & 14.8 & 11.0 & 3,8 & 14,44 \\
\hline S13 & 15.0 & 9.3 & 5,7 & 32,49 \\
\hline S14 & 13.7 & 10.3 & 3,4 & 11,56 \\
\hline S15 & 14.5 & 11.0 & 3,5 & 12,25 \\
\hline S16 & 13.0 & 12.0 & 1 & 1 \\
\hline S17 & 12.4 & 10.2 & 2,2 & 484 \\
\hline S18 & 13.3 & 11.2 & 2,1 & 4,41 \\
\hline S19 & 12.0 & 10.0 & 2 & 4 \\
\hline S20 & 14.5 & 12.0 & 2,5 & 6,25 \\
\hline
\end{tabular}

Based on the table above, it is known that the results of the study were the differences in the value of hemoglobin before menstruation and after menstruation from 20 samples. On the hemoglobin examination before menstruation, the highest hemoglobin value was $16.2 \mathrm{gr} / \mathrm{dl}$ and the lowest hemoglobin value was 12.0 gr / dl. Meanwhile, on post-menstrual hemoglobin examination, the highest hemoglobin value was $12.7 \mathrm{gr} /$ $\mathrm{dl}$ and the lowest hemoglobin value was $9.3 \mathrm{gr} / \mathrm{dl}$. To test the hypothesis, namely; There is a significant difference between $\mathrm{Hb}$ before menstruation and postmenstruation among students majoring in Sports Education. For more details, it can be described as follows:

$$
\begin{aligned}
& t_{\text {test }}=\frac{\bar{x}_{1}-\bar{x}_{2}}{\sqrt{\left(s_{1}^{2} / n_{1}\right)+\left(s_{2}^{2} / n_{2}\right)}} \\
& t_{\text {test }}=\frac{3.13}{1,15} \\
& t_{\text {hiung }}=2,745 \\
& \text { degress of free }(\mathrm{db})=20-1=19 \\
& t_{\text {tabel }(0,05 ; 20)}=2,093
\end{aligned}
$$

$t_{\text {hitung }}=2,745>t_{\text {tabel }}=2,093$, then there is a significant difference between $\mathrm{Hb}$ before menstruation and postmenstruation among students majoring in Sports Education.

\section{b. Discussion}

According to the researcher, the decrease in hemoglobin levels in post-menstrual blood in the whole sample is because during menstruation, women experience a lot of blood loss of $30-50 \mathrm{ml}$ per day. The 
amount of blood loss accompanied by dizziness, fatigue, lethargy and weakness during menstruation can trigger symptoms of anemia. Anemia occurs because the hemoglobin level in the blood is less than normal which is caused by many things including menstruation. To minimize the symptoms of anemia during menstruation, treatment can be done, such as taking iron-boosting drugs or consuming foods that contain lots of iron and avoiding doing heavy work so as not to trigger excessive fatigue during menstruation.

According to (Wahyuningsih and Astuti, 2012), a lack of hemoglobin levels in the blood can cause nerve cells and metabolism in the body work not optimally. If the hemoglobin level in the blood becomes low, it will trigger symptoms of mild anemia, anemia is a condition in which a person's hemoglobin level is less than normal values. This is due to a decrease in the quality and quantity of red blood cells. Mild anemia can also affect the ability to concentrate in studying, reduce physical abilities, reduce body freshness, pale face, dizziness, decreased immunity so that it is prone to disease and feeling tired, tired and lethargic which also causes decreased productivity.

The decrease in hemoglobin levels in the blood is caused by many factors, such as lack of consumption of foods containing iron, chronic disease, imbalance between activities and nutritional intake and blood loss due to menstruation. During menstruation, women often feel dizzy, weak and tired. This happens because during menstruation, women lose a lot of blood and as a result iron levels are low and as a result, hemoglobin levels are also low so that they are less than normal values. (Prastika, 2011).

\section{CONCLUSION}

Based on the results of research on differences in hemoglobin levels before menstruation and postmenstruation in students majoring in Sports Education, which was carried out at the Faculty of Sport Sciences, University of Padang are:

1. The value of the hemoglobin level before menstruation of the whole sample is normal

2. The value of post-menstrual hemoglobin in the sample becomes low

3. From the results of the study, differences in hemoglobin levels before menstruation and postmenstruation in all samples show significant results (there are differences)

4.

\section{REFERENCES}

[1] Adriana, Utomo Waras Budi, dan Febrianti, (2013). Lama Haid dan Kejadian Anemia pada Remaja Putri, Fakultas Kedokteran dan Ilmu Kesehatan
Universitas Islam Negeri Syarif Hidayatullah Jakarta, Volume 4, Nomor 1.

[2] Engka Joice N.A, Tombokan Kevin C, dan Pangemanan Damajanty H. C, (2017). Hubungan antara Stress dan Pola Siklus Menstruasi pada Mahasiswwa Kepaniteraan Klinik Madya di RSUP Prof. Dr. R. D. Kandou Manado, Fakultas Kedokteran Universitas Sam Ratulangi Manado, Volume 5, Nomor 1.

[3] Fa'iza Qorina Sabila, Setiani Onny, dan Joko Tri, (2016). Perbedaan Kadar Hemoglobin (Hb) dalam Darah Sebelum dan Sesudah Konsumsi Air Kelapa Hijau (Green Coconut Water) pada Pekerja yang Terpapar Timbal $(\mathrm{Pb})$ di Karoseri $X$ Semarang, Volume 4, Nomor 3.

[4] Felicia, Hutagaol Esther, dan Kundre Rina, (2015). Hubungan Status Gizi dengan Siklus Menstruasi pada Remaja Putri di PSIK UNSRAT Manado, Fakultas Kedokteran Universitas Sam Ratulangi Manado, Volume 3, Nomor 1.

[5] Gandasoebrata, (2013). Penuntun Laboratorium Klinik

[6] Gunadi Valerie I. R, Mewo Yanti M, dan Tiho Murniati, (2016). Gambaran Kadar Hemoglobin pada Pekerja Bangunan, Fakultas Kedokteran Universitas Sam Ratulangi Manado, Volume 4, Nomor 2

[7] Kristianti Septi, , Winarsih, dan Wibowo Trisno Agung, (2013). Hubungan Anemia dengan Siklus Menstruasi pada Remaja Putri di SMA Negeri 1 Imogiri, Yogyakarta, Volume 3, Nomor 1.

[8] Notoatmodjo, S. Prof. Dr, (2010). Metodelogi Penelitian Kesehatan. Pencipta Rineka Cipta, Jakarta

[9] Nugrahani Ika, (2013). Perbedaan Kadar Hemoglobin Sebelum dan Sesudah Menstruasi Pada Mahasiswa DIII Keperawatan, Universitas Muhammadiyah Surakarta.

[10] Nursalam, (2008). Konsep dan penerapan Metodelogi Penelitian Ilmu Keperawatan, salemba medika, Jakarta.

[11] Prastika Dewi Andang, (2011). Hubungan Lama Menstruasi terhadap Kadar Hemoglobin pada Remaja Siswi SMA N l Wonosari, Fakultas Kedokteran Universitas Sebelas Maret Surakarta.

[12] Utami Baiq Nurlaily, Surjani, dan Mardiyaningsih Eko (2015). Hubungan Pola Makan dan Pola Menstruasi dengan Kejadian Anemia Remaja Putri, Akademi Kebidanan dan Akademi Keperawatan Ngudi Waluyo Ungaran, Volume 10, Nomor 2

[13] Wahyuningsih Astuti, dan Astuti Sari Puji, (2012). Hubungan Kadar Hemoglobin dengan Keteraturan Siklus Menstruasi pada Mahasiswi Prodi D IIII 
Kebidanan Tingkat III, Stikes Muhammadiyah Klaten, Volume 2, Nomor

[14] Fa'iza Qorina Sabila, Setiani Onny, dan Joko Tri, (2016). Perbedaan Kadar Hemoglobin (Hb) dalam Darah Sebelum dan Sesudah Konsumsi Air Kelapa Hijau (Green Coconut Water) pada Pekerja yang Terpapar Timbal $(P b)$ di Karoseri $X$ Semarang, Volume 4, Nomor 3.
[15] Felicia, Hutagaol Esther, dan Kundre Rina, (2015). Hubungan Status Gizi dengan Siklus Menstruasi pada Remaja Putri di PSIK UNSRAT Manado, Fakultas Kedokteran Universitas Sam Ratulangi Manado, Volume 3, Nomor. 